\title{
Imagining citizenship in the Levellers and Milton
}

Book or Report Section

Accepted Version

Foxley, R. (2019) Imagining citizenship in the Levellers and Milton. In: Cuttica, C. and Peltonen, M. (eds.) Democracy and Anti-Democracy in Early Modern England 1603-1689. History of European Political and Constitutional Thought. Brill, Leiden. ISBN 9789004385986 Available at http://centaur.reading.ac.uk/73021/

It is advisable to refer to the publisher's version if you intend to cite from the work. See Guidance on citing.

Publisher: Brill

All outputs in CentAUR are protected by Intellectual Property Rights law, including copyright law. Copyright and IPR is retained by the creators or other copyright holders. Terms and conditions for use of this material are defined in the End User Agreement. 


\section{www.reading.ac.uk/centaur}

\section{CentAUR}

Central Archive at the University of Reading

Reading's research outputs online 


\section{Imagining Citizenship in the Levellers and Milton}

Democracy was a mutable concept in the republican writings of the interregnum period. In Marchamont Nedham's hostile characterisation of the type of 'Democratick, or Popular Forme' which he attributed to the Levellers at the outset of his republican career, democracy favoured 'licentiousnesse' and the rule of the 'lowest of the People', becoming a kind of 'Tyranny'; in formal terms it put 'the whole multitude of the people into the equall exercise of the Supreme Authority'. ${ }^{1}$ But in James Harrington's Oceana of 1656, 'democracy' became a term which could describe a highly stratified, mediated, and controlled exercise of ultimate popular sovereignty, wildly distant from Nedham's hackneyed but nightmarish vision of mob

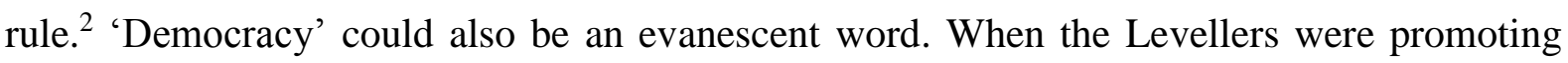
the rule of an annually-elected unicameral representative, Nedham labelled this 'democracy' but the Levellers did not. When Nedham himself started to promote the rule of an annuallyelected unicameral representative, he too ceased to call such a system a democracy. When Harrington's avowedly democratic scheme of government became central to the rather desperate republican debate of 1659-60, his worried rivals began optimistically to insist that some aura of 'democracy' might attach to their very different and (to our eyes) even less democratic proposals too. ${ }^{3}$

This tactical flexibility in the use or non-use of 'democracy' for a whole range of nonmonarchical constitutional proposals which invoked the authority of the people is my justification - or my excuse - for using this chapter to compare the writings of the Levellers and of John Milton, who both steered almost entirely clear of the language of democracy, but were enmeshed in these evolving debates about what the power of the people might mean, how it could be exercised, and, at some points, what it could be called. The subject of this chapter is citizenship - the boundaries of citizenship, the duties and qualities of citizens, and the language which the Levellers and Milton used in constituting a body of citizens in their writings and in policing the attributes and boundaries of that citizen body. By exploring this language, I am intervening in ongoing scholarly debates which have implications for our

\footnotetext{
${ }^{1}$ Marchamont Nedham, The Case of the Common-wealth of England, Stated (1650), pp. 71-2, 74. All pre1700 works cited were published in London.

${ }^{2}$ Rachel Foxley, 'Democracy in 1659: Harrington and the Good Old Cause', in Grant Tapsell and Stephen Taylor (eds), The Nature of the English Revolution Revisited (Woodbridge: Boydell and Brewer, 2013), pp. 17596; Rachel Hammersley, 'Rethinking the Political Thought of James Harrington: Royalism, Republicanism, and Democracy', History of European Ideas, 39:3 (2013), pp. 354-70; Eugenio Capozzi, 'Republicanism and Representative Democracy: the Heritage of James Harrington', European Review of History/Revue Européenne d'Histoire, 5:2 (1998), pp. 197-204.

${ }^{3}$ Foxley, 'Democracy in 1659 '.
} 
understanding of early modern talk about democracy. This chapter sheds light on the debated relationship between the political thought of the Levellers and that of classical republicans, arguing that in spite of profound similarities between the Levellers' and Milton's thought, the ways in which they developed key elements of their thought ultimately yielded very different visions of the citizen body. My argument supports the developing consensus which is increasingly breaking down any rigid boundary between 'liberal' and 'republican' thought in the early modern period: both the Levellers and Milton used characteristic elements of both traditions, and it was the way in which they fleshed these out, rather than their simple use of ideas of rights, consent, freedom as non-domination, or political virtue, which determined the ultimate character of their thought. Although my reading tends to reinforce interpretations of the Levellers as remarkably radical, and of Milton as more ambivalent about the potential of the people for citizenship, it shows that such views could grow from shared intellectual foundations.

\section{LEVELLERS AND REPUBLICANS}

The relationship between Leveller thought and republicanism has drawn recurring interest from scholars. Samuel Glover, setting up a distinction between popular and elitist republicanism, argued that the Leveller movement of the 1640s was more deeply influenced by classical republican theory than had been recognised, and that classical texts could be plundered for justifications for the political equality of the poor. ${ }^{4}$ Others have seen this more plebeian republicanism apparent in some of the 1650s republican authors and have also drawn comparisons with the Levellers. ${ }^{5}$ In the case of Milton, a tantalising gap in the historical record - the lack of an explanation for his failure to fulfil a commission to write against the Levellers - has led to speculation about his possible sympathy for aspects of Leveller thought. An extensive, though to my mind problematic, case for this sympathy has recently been made by David Williams in his book Milton's Leveller God, but the argument

\footnotetext{
${ }^{4}$ Samuel Dennis Glover, 'The Putney Debates: Popular Versus Élitist Republicanism', Past \& Present, 164 (1999), pp. 47-80.

5 Nigel Smith, 'Popular Republicanism in the 1650s: John Streater's "Heroick Mechanicks"', in David Armitage, Armand Himy and Quentin Skinner (eds), Milton and Republicanism (Cambridge: Cambridge University Press, 1995), pp. 137-55. I have discussed the relationship between Leveller and republican thought at more length in Rachel Foxley, The Levellers: Radical Political Thought in the English Revolution (Manchester: Manchester University Press, 2013), ch. 6.
} 
is not new. ${ }^{6}$ Although this chapter will ultimately argue against an over-assimilation of Levellers and republicans, we will see that there are fertile grounds for comparison.

Many of the structures of thought present in Leveller writing can also be found in republican texts. The growth of scholarship which identifies an early modern tradition synthesising 'republican' with 'liberal' elements of thought helps to draw the two closer together, highlighting the fact that few republican texts of the period are devoid of ideas of rights and consent to government. ${ }^{7}$ It is rare for either a Leveller or a Miltonic text to pause for long enough to set out an elaborated theory of freedom and government, but at the moments which come closest, they sound remarkably similar. Milton argued that 'all men naturally were borne free' and were 'born to command and not to obey'. ${ }^{8}$ Leveller authors similarly emphasized the original freedom of every man (and, in Lilburne's case, woman), but added an explicit statement of original equality which was not there in that Miltonic account. For Lilburne, all humans 'are, and were [since the Creation of Adam and Eve] by nature all equall and alike in power, dignity, authority, and majesty'. ${ }^{9}$ For Overton, 'by naturall birth, all men are equally and alike borne to like propriety, liberty and freedome'. ${ }^{10}$ Tellingly, when Milton did offer an account which emphasised that 'prime Nature made us all equall' he did not, like Lilburne and Overton, bring this equality into the present by using present-tense verbs, but explained that human imperfection - the Fall - had led people decisively away from this original state. ${ }^{11}$ However, the implications of the theory for political legitimacy were the same for the Levellers and Milton: those born free could only rightly be ruled by their own consent. Such ideas might, in the Leveller as well as the republican texts, be combined with more typically 'classical republican' elements, including an emphasis on the moral qualities and duties of citizenship. Furthermore, the characterisation of liberty in terms of freedom from domination, which for Skinner is the key

\footnotetext{
${ }^{6}$ David Williams, Milton's Leveller God (Montreal \& Kingston: McGill-Queen's University Press, 2017); for a review of the scholarship and a verdict which rejects the hypothesis of Milton's sympathy with the Levellers on the basis of very different approaches to the law, see Martin Dzelzainis, 'History and Ideology: Milton, the Levellers, and the Council of State in 1649', Huntington Library Quarterly 68 (2005), pp. 269-87.

7 Vickie B. Sullivan, Machiavelli, Hobbes, and the Creation of a Liberal Republicanism in England (Cambridge, 2004); Christopher Hamel, 'The Republicanism of John Milton: Natural Rights, Civic Virtue and the Dignity of Man', History of Political Thought, 34:1 (2013), pp. 35-65.

${ }^{8}$ Notes to Milton's works are to the Yale edition unless otherwise stated: D. M. Wolfe et al. (eds), Complete Prose Works of John Milton (New Haven and London: Yale University Press, 1953-1982), 8 vols (hereafter CPW), 3.198-9.

9 John Lilburne, The Free-mans Freedom Vindicated (1646), p. 11.

${ }^{10}$ Richard Overton, An Arrow against all Tyrants and Tyrany (1646), p. 3.

${ }^{11}$ CPW 2.661; Martin Dzelzainis, 'The Politics of Paradise Lost', in Nicholas McDowell and Nigel Smith (eds), The Oxford Handbook of Milton (Oxford: Oxford University Press, 2009), pp. 547-68, p. 558.
} 
to a distinctively early modern republican system of values, also meshed neatly with the argument that authority needed consent (this would ensure that authority was nondominating). The structural foundations of Leveller and Miltonic political argument were thus extremely similar.

These deep structural similarities between Leveller thought and key points of Milton's republicanism, however, do not mean that Leveller and republican discourses blend seamlessly together. The feel of most Leveller writing is very different from Milton's classical republicanism - with some telling exceptions. This difference in feel is partly, and revealingly, a matter of written style. The Levellers did not always live up to their selfpresentation as plain speakers who distrusted the tricks of rhetoric, but there is still a world of difference between their polemical pamphlets and the grammatical and stylistic elaboration of Milton's English prose. ${ }^{12}$ Milton regretted exposing the reasoning of his divorce tracts to an English-speaking audience rather than couching it in Latin; Leveller authors sought the widest possible audience of 'free-born Englishmen' for their texts, and sought understanding through English, even when reading classical texts. Even though Richard Overton critiqued the pedantry and exclusivity of humanist education, it may be no accident that it was this Cambridge-educated Leveller leader who often appears most similar to Milton in some of his attitudes to citizenship and the people. ${ }^{13}$ But the differences between the Levellers and Milton's political rhetoric go well beyond issues of style. Even when they were constructing arguments based on the same foundations, invoking the same value systems, and using overlapping vocabulary, they did so in ways which opened up significant political space between them. In this essay I will explore the rhetorical strategies which create or reveal these differences.

\section{THE BOUNDARIES OF CITIZENSHIP}

Both the Levellers and Milton rested essential arguments on the authority of 'the people', but it was never simple to translate this authorising concept into a clearly-defined citizen body of those eligible to act for that people electorally and in other civic duties. When the Levellers and Milton talked about the qualities their citizens required, who were they even including within the bounds of citizenship? The fluctuations and contortions of Milton's

\footnotetext{
12 For the Levellers' attitude to rhetoric, see Rachel Foxley, "The wildernesse of tropes and figures": Figuring Rhetoric in Leveller Pamphlets', Seventeenth Century, 21:2 (2006), pp. 270-86.

${ }^{13}$ See Nicholas McDowell, The English Radical Imagination (Oxford: Oxford University Press, 2003), ch. 3, for Overton's critique of humanist education.
} 
relationship with the English people ('populus') which he set out to 'defend' in his Latin propaganda have been the subject of much scholarship. ${ }^{14}$ The Levellers' scattered and inconsistent franchise proposals also formed the basis for a long-running debate, recently revived by Phil Baker, about how inclusive or exclusive their citizen body was supposed to be. ${ }^{15}$

Although the scholarship responding to Macpherson redeemed the Levellers from the accusation that they would exclude all wage-earners from the franchise, revisionist work still foregrounded the exclusions which were contemplated or prescribed by Levellers and army radicals, and further fertile work on the Levellers has looked for the roots of their ideas of citizenship in the world of London freemen, an exclusive group. Thus Baker points out that as late as September 1648 the Levellers were demanding the restoration of the specific privilege of the exclusive group of the freemen of London - the 'comonalty' of London - to elect their Common Councillors - an expansion beyond the current practice, but falling short of the harmonised electoral qualifications which applied to both national and local elections in the third Agreement of the People in May $1649 .{ }^{16}$ In that final programmatic statement, the Levellers came as close as they ever did to enacting the right of Rainborowe's 'poorest hee' to elect, but there were still exclusions on the basis of gender, age, economic dependence, and political allegiance: '(according to naturall right) all men of the age of one and twenty yeers and upwards (not being servants, or receiving alms, or having served in the late King in Arms or voluntary Contributions) shall have their voices. ${ }^{17}$ This was not the most restrictive of the franchise proposals put forward by or in association with the Levellers; it actively removed the 'householder' requirement of the Officers' Agreement, retained, as Phil Baker points out, even in Lilburne's dissident version. ${ }^{18}$ But the Levellers also drew on traditionally exclusive entitlements - 'rights', 'liberties', 'privileges' and 'franchises' - in ways which did not respect their exclusivity. These entitlements, in Lilburne's powerful rhetoric, became the rights of all 'free-born Englishmen', a phrase which reverberated through Lilburne's writing

14 Distinguished book-length studies are Sharon Achinstein, Milton and the Revolutionary Reader (Princeton: Princeton University Press, 1994); Paul Hammond, Milton and the People (Oxford: Oxford University Press, 2014).

${ }^{15}$ Philip Baker, 'The Franchise Debate Revisited: the Levellers and the Army', in Taylor and Tapsell (eds) The Nature of the English Revolution Revisited, pp. 103-22. The debate was initiated by C. B. Macpherson, The Political Theory of Possessive Individualism: Hobbes to Locke (Oxford: Oxford University Press, 1962).

${ }^{16}$ Baker, 'Franchise Debate', p. 115; but see also Rachel Foxley, 'John Lilburne and the Citizenship of 'freeborn Englishmen', Historical Journal, 47:4 (2004), pp. 849-874, pp. 852-4 on Lilburne's willingness to undermine the exclusivity of the term 'freemen'.

${ }^{17}$ An agreement of the free people of England (1649), p. 3. Royalists were to be excluded for ten years only.

18 Baker, 'Franchise Debate', p. 120. 
and set up a powerful vision of apparently equal and collective entitlements, even if actual proposals were less generous. ${ }^{19}$ Natural right and English birth together grounded an inclusive citizenship, which relatively small numbers forfeited or could not exercise due to economic dependence.

Milton rarely engaged in constitutional prescription, so it is harder to pin down proposals which can be compared with his rhetoric. But aspects of his argumentation are very telling. Because he was defending the actions of a partisan and purged parliament whose claim to speak for the people was transparently contradicted by the public mood, Milton often used argumentative sleights of hand to claim for a minority the right to act for the whole people. ${ }^{20}$ This recurrent argument may not have been intended to establish the bounds of citizenship itself, limiting it to a politically and ethically sound minority, but at least in extremis, Milton was willing to contemplate very significant restrictions. In his writings resisting the restoration, Milton did propose a constitutional mechanism, a Grand Council, whose members would initially be 'chosen by the people', but who were ideally to sit for life. ${ }^{21}$ Resisting calls for rotation, successive re-elections of the whole body, or the establishment of a popular assembly to sit alongside the Grand Council, in the second edition of the Readie and Easie Way Milton considered measures which could mitigate the danger of such courses. One possibility, if electoral politics was to be given a place, was to 'wel-qualifie and refine elections', entrusting even the first round of a multi-stage electoral process not to 'a rude multitude' but 'only [to] those of them who are rightly qualifi'd', and committing further rounds of winnowing of candidates to 'others of a better breeding' to ensure that only the worthiest were elected. ${ }^{22}$ Milton thus envisaged not only a hierarchy between electors, but the exclusion of some from electoral citizenship altogether, although he was silent on what would qualify some and exclude others. One candidate for that criterion was the intellectual or moral capacity of potential citizens.

\section{IMAGINING CITIZENS}

Both the Levellers and Milton drew on powerful descriptive vocabularies and associations to paint a picture of the citizen qualities they wished to see, and, in some cases, of the ways in

\footnotetext{
${ }^{19}$ Foxley, 'John Lilburne and the Citizenship', passim.

${ }^{20}$ CPW 3.197; CPW 4.1.457; CPW 7.455.

${ }^{21}$ CPW 7.368; 7.432.

${ }^{22}$ CPW 7.442-3.
} 
which citizens could fall short of what was desirable. Thus they constructed and policed an idealised citizen body.

Both Milton and the Levellers saw people's intellectual and moral abilities as key to their ability to save or serve the polity. Indeed, the positive vocabulary both used suggested the importance of a certain combative and practical kind of virtue, a moral courage which would help to defend political liberty. At one level, too, both tended towards generous assumptions about the moral potential of the population, assumptions which were perhaps grounded in theological beliefs about salvation, but which can be seen to have further ramifications in political terms. William Walwyn, in a typically expansive self-depiction, claimed to 'truly and heartily love all mankind, it being the unfeigned desire of my soul, that all men might be saved, and come to the knowledge of the truth. ${ }^{23}$ Walwyn's theology of universal grace, but not necessarily universal salvation, had much in common with Milton's belief that all could be saved, if they exercised their freedom to accept this grace. Of course, while theology and politics were clearly intertwined for Milton and the Levellers, we should not assume a direct translation of spiritual equality into political terms. Milton's republicanism itself was grounded in the Aristotelian assessment that the distribution of merit in the population was more equal than to justify or tolerate a king: in 1651 he went so far as to say that the 'majority' of men were 'equal' 'in every state'; by 1660, discussing the same Aristotelian principle, he had retreated to the assertion that the nation need not 'fear a scarcitie of able and worthie men' if they were diligently sought out. ${ }^{24}$ As we have already seen, the Levellers' characterisation of equality was rather more robust, as they asserted it to have been the original condition not only of mankind in an ancient state of nature but of everyone at their birth; this equality persisted and was fundamental to Leveller thought. In spite of this, however, both the Levellers and Milton sometimes castigated people's moral or intellectual failings - in the context of their political failings - in ways which linked them with lowly social status.

For Milton, it was 'the vulgar folly of men to desert their own reason, and shutting thir eyes to think they see best with other mens.' 25 The hint of social judgement in 'vulgar'

${ }^{23}$ William Walwyn, A vvhisper in the eare of Mr. Thomas Edwards minister (1646), pp. 2-3.

${ }^{24}$ Milton, 'A Defence of the People of England', transl. Claire Gruzelier, in Martin Dzelzainis (ed), Milton. Political Writings (Cambridge: Cambridge University Press, 1991), p. 99; the original reads: 'ubi multi sunt aequales, ut sunt in omni civitate plurimi': Columbia 7.126; CPW 7.449. This position of 1660 perhaps echoes Milton's argument in the Tenure that a Christian prince should be aware that his nation will contain 'so many thousand Men' superior to him in virtue: CPW 3.204-5.

${ }^{25}$ CPW 3.212. 
(although its main signification here is simply 'common') suggests that the active use of reason was unlikely to be found at the lowest levels of society, who were - wilfully - in the habit of being led. These tropes were common, and the Levellers occasionally resorted to them too. Overton reminds us of Milton when he talks of the 'inconsiderate Multitude, whose judgements are guided by custome, more then by reason,' a thought which Walwyn echoed, in spite of his usual generous assertions about the capacity of all for understanding, when he argued that 'most men are transported with flashy fancies, and are unapt to consider things judiciously. ${ }^{, 26}$ Even Lilburne, when he thought he might end up on the rough end of the crowd rather than having it doing his bidding, was afraid that his enemies might manipulate the 'rude multitude' into stoning him or tearing him apart. ${ }^{27}$ In general, however, the Levellers avoided the use of the language of status or social description to make pejorative points. They resisted the characterisation of their supporters as the lowest of the low, and suggested economic solidity, middling social status, and perhaps moral substance too when they described them as 'industrious and laborious' or 'nown-substantive'. ${ }^{28}$ But ultimately they argued that 'the greatest Peers in the Land' should be no more 'respected ... then somany [sic] old Bellowes-menders, Broom men, Coblers, Tinkers or Chimney-sweepers, who are all equally Free borne, with the hudgest men, and loftiest Anachims in the Land. ${ }^{29}$ Milton, although his instincts too were to trust to the middling sort, ${ }^{30}$ by contrast seasoned his works liberally with the vocabulary of social denigration, often using it in contexts which implied the intellectual or moral inferiority of the lower ranks of society. He almost obsessively differentiated the 'Worthies' and 'men of noblest temper' (note the approbatory use of 'noble', another term of social status) from 'Vulgar and irrational men' prone to 'sloth or inconstancie'. ${ }^{31}$ Social status appeared to be strongly correlated with moral qualities. It was possible for people to rise above their origins and achieve 'true nobility', becoming (in Claire Gruzelier's neat translation) 'their own ancestors' through their worth; ${ }^{32}$ but, as we will see, it was also possible for a woman to rise above her gendered status or a man to fall

\footnotetext{
${ }^{26}$ Richard Overton, The Commoners Complaint (1647), p. 4; William Walwyn, An Antidote against Master Edwards his old and new Poyson (1646), p. 19.

${ }^{27}$ John Lilburne, Londons Liberty in Chains Discovered (1646), p. 31.

${ }^{28}$ Richard Overton, An Alarum to the House of Lords, p. 8.

${ }^{29}$ Overton, An Arrow against all Tyrants, pp. 19-20.

${ }^{30}$ Hammond, Milton and the People, pp. 168-9. He must, however, have had in mind a rather higher echelon of 'middling' given his scorn for shopkeepers as well as labourers ('operas et tabernarios') as the dregs ('faex') of the people: ibid., p. 165.

${ }^{31}$ CPW 3.192.

${ }^{32}$ Milton, 'A Defence of the People of England', in Dzelzainis (ed), Milton. Political Writings, p. 62; 'veram nobilitatem' 'ex se natos': Columbia 7.32.
} 
below his, without that affecting Milton's view of men's natural superiority: we should not assume that these social terms are 'mere' metaphors, although even as metaphors they are extremely telling.

But Milton, at some points, had high hopes for his fellow countrymen, who were certainly not born to be slaves. It was partly education which would help them to understand, love and deserve liberty, and the educative impulse was a constant in Leveller writings too: it was not to be taken for granted that people knew their liberties and were impassioned about defending them. Both the Levellers and Milton were concerned to ensure that the people were equipped to defend their liberties: the Levellers' writings were relentlessly and self-consciously educative in their repetitious exposition of native and natural liberties, while Milton in both Of Education and his political works understood education as fitting men for civic life although his was an extensive programme of education which only 'our noble and our gentle youth' were likely to access. ${ }^{33}$ But again, divergences did open up between them. The Leveller authors tended (although not without exception) to assume that the essentials of religious and political life were easily understood, and that the people would be able to grasp them as long as they were not prevented from doing so by the oppression and deception (the two went together) of abusive elites. For Milton, however, that extensive but exclusive education may have been necessary to attain sufficient wisdom at least for any active role in politics - without it, people would default to irrationality.

Ultimately, Milton's demanding conception of virtue as moral choice, even though it had no necessary political or social corollaries, seemed to push towards a moral exclusivity which was in danger of taking on a kind of social exclusivity too. Milton often denigrated the importance of mere numbers when compared against virtue: it was not the actions of the whole nation, or even the whole parliament, which counted, but those of the sanior pars. ${ }^{34}$ His lofty conception of individual virtue led him to envisage it, almost by definition, as displayed through resistance against the pressures of custom and tides of feeling which swayed the multitude. It came to seem almost inevitable that virtue was the property only of a few. In his divorce tracts, Milton charitably urged that laws be made which accommodated realistically the weakness of the 'common lump of men' who were not 'heroically vertuous'; at other times he was less forgiving of that weakness, and exemplars of virtue, particularly in politics, were those who stood against the crowd. Judges, magistrates, and commanders'

\footnotetext{
${ }^{33}$ CPW 2.378, 406; CPW 7.443 ('To make the people fittest to chuse, and the chosen fittest to govern, will be to mend our corrupt and faulty education').

${ }^{34}$ CPW 3.197; CPW 4.1.457: 'pars... sanior' means 'the sounder part'; CPW 7.455.
} 
display of 'civill prudence' was assessed by whether they had the 'magnanimity' or 'fortitude' to stand by their own 'judgment' against the 'obstinacie of [the] heard' or 'the rashnes and the clamours of their own Captains and confederates', holding out against 'what the boisterous Tribunes and Souldiers bawl'd for. ${ }^{35}$

By contrast, the Levellers' moral condemnations tended to be reserved for the vices of exploitative rulers: if the people were in danger of being enslaved to anyone's lusts, it was those of their rulers, not their own. Thus Lilburne warned that the army would be used to serve 'a few mens lusts and lawlesse Pleasures', and that a small number of men were attempting to 'enslave the Common-wealth, to their owne Pride, Ambition, Lusts, Covetousnesse, and Domination if not Dukeship, or Kingship' ${ }^{36}$ While Milton emphatically agreed that the tyrants and courtiers were as vicious as the broader populace who deferred to them, the Levellers had a far more vivid sense of the moral flaws of the rulers - to some extent, perhaps, echoing Machiavelli's sense of the characteristic passions of the dominant elite - than of the ruled. That even applies to Overton's most despairing rhetoric, which has something in common with Milton's tendency to binary moral classification into 'good men' and 'bad men'. Thus in 1647, when he was appealing from the fatally corrupted authority of parliament to the people at large, Overton anathematised anyone who endangered the human rights and freedoms which enable human society as an 'enemy to mankinde', and saw 'this our Common-wealth swarming with such Monsters in nature and humanity'. ${ }^{37}$ This vision drew on Cicero's discussion of tyranny - later used by Milton in his justification for regicide - which saw tyrants as 'fierce and savage monsters in human form' who 'should be cut off from what may be called the common body of humanity'. ${ }^{38}$ Overton here applied this to the collective tyranny of 'usurpers and oppressors' in parliament and their 'unnatural faction', but he still expressed hope that 'every rationall honest Common-wealths man', under the leadership of the army in default of a valid parliament, could act together to prevent catastrophe. The wicked were to be 'purged', but Overton still imagined a strong body of citizens with the capacity to do so. ${ }^{39}$

\footnotetext{
${ }^{35}$ CPW 2. 253; 314-5.

${ }^{36}$ John Lilburne, The second part of Englands new-chaines discovered (1649), pp. 8, 16.

${ }^{37}$ Richard Overton, An Appeale from the Degenerate Representative Body (1647), p. 26.

${ }^{38}$ CPW 3.212; Cicero, De Officiis Book 3.6.32, trans. Walter Miller, Cicero, On Duties (Cambridge, MA: Loeb Classical Library, 1913) p. 299; 'sic ista in figura hominis feritas et immanitas beluae a communi tamquam humanitatis corpore segreganda est.'

${ }^{39}$ Overton, An Appeale, pp. 26-7.
} 
Milton's emphasis on virtue as resistance against the pressure of the many was so consistent that even though the multitude had contributed to the liberation of the country from Charles I's tyranny in the civil war, Milton retrospectively denigrated their actions as the result of the desire for 'noveltie' which afflicted 'most men', only briefly countenancing the thought that these men had propounded to themselves just ends, before insisting that their 'sloth or inconstancie, and weakness of spirit', or even their 'inbred falshood and wickedness' meant that they inevitably failed to sustain the cause. ${ }^{40}$ As Paul Hammond comments, Milton only 'temporarily recuperates' the reputation of the 'people', 'multitude' and 'vulgar' who constituted the crowd when turning round the royalist narrative in Eikonoklastes; ultimately he still condemned their 'fickleness and instability'. ${ }^{41}$ This kind of language is vanishingly rare in Leveller texts, unsurprisingly given Lilburne's own involvement in the crowd action of the early $1640 \mathrm{~s}^{42}$ and the Levellers' willingness to mobilise the crowd in an extra-constitutional way. The Levellers' references to the multitude, or to multitudes of people, were generally emphatic rather than denigratory, in marked contrast to Milton's.

\section{CITIZENSHIP AND SLAVERY}

Citizens, by definition, were not slaves. The powerful language of slavery was woven through both the Levellers' and Milton's writings, creating a vivid picture of the threats hanging over the population. Milton and the Levellers were working from a shared theory of (political) slavery as dependence on another's will, but their divergent uses of the theory resulted in different pictures of the citizen body. For the Levellers, largely uncorrupted citizens were faced with an external threat of slavery; for Milton, the citizen population itself was in danger of becoming servile.

Both the Levellers and the classical republicans drew on the neo-Roman idea of liberty to argue that dependence on the will of another was a total deprivation of freedom, resulting in slavery. The Levellers constantly characterised the political oppression and danger which they and the nation faced in terms of slavery. As Lilburne's pamphlet titled Liberty Vindicated Against Slavery suggests, in the neo-Roman model, political liberty and slavery were binary alternatives. In mid-1649 Lilburne argued that the effect and intention of Pride's

\footnotetext{
${ }^{40}$ CPW 3.192.

${ }^{41}$ Hammond, Milton and the People, pp. 136-7; CPW 3.578.

42 Philip Baker, 'Londons Liberty in Chains Discovered: The Levellers, the Civic Past, and Popular Protest in Civil War London,' Huntington Library Quarterly, 76:4 (2013), pp. 559-87, p. 567.
} 
Purge had been 'by force of arms to ... subject them [the people] to perfect vassalage and slavery'; this slavery arose from being subjected to another's will, rather than able to choose their own governors: not even a 'thousand[th] part' of the people of England had 'authorised Thomas Pride, with his Regiment of Souldiers, to chuse them a Parliament. ${ }^{43}$ This conception of political slavery was shared with many of the classical republican authors, and Quentin Skinner has used Milton as a key exemplar of this kind of thinking. ${ }^{44}$ However, while the core 'neo-Roman' definition of liberty as the absence of enslavement to another's will was shared by Milton and the Levellers, its argumentative implications and the rhetoric associated with it could be developed in divergent directions.

One of the puzzles about the ubiquitous political language of slavery in this period is what relation, if any, it bore to the existence of the actual slavery whose horror it drew on rhetorically. Mary Nyquist rightly warns that we should not be misled by the 'obfuscatory privileging of figurative slavery' over actual slavery in Milton's texts into assuming that he condemned the institution outright. ${ }^{45}$ Steven Jablonski has made a compelling case that Milton endorsed the Aristotelian idea of natural slavery in the case of Africans, and found slavery to be in accordance with the secondary laws of nature which responded to a fallen world. In Jablonski's reading of Milton, rightful deprivation of political liberty is simply one of a hierarchy of states of slavery which were justified by irrationality. ${ }^{46}$ The Levellers, by contrast, did not hint at any legitimate form of slavery. Milton's reconciliation of slavery with original freedom was only possible through an emphasis on the Fall separating us from that original freedom - which was not the Levellers' position. While for Milton government itself might be a consequence of the Fall, for the Levellers consenting government was compatible with an unfallen state. ${ }^{47}$ They rejected the possibility of voluntary slavery outright: 'according to the Law of God, Nature, and Reason... it is not lawfull for any man to subject himself, to be a slave'. ${ }^{48}$ Milton, of course, was able to use similar arguments when he invoked slavery in a political sense: for those who had the capacity and opportunity to be free ('any freeborn man') it was utterly shameful to submit to slavery, and to reduce oneself to the

\footnotetext{
${ }^{43}$ John Lilburne, The Legall Fundamentall Liberties (1649), title page.

${ }^{44}$ Quentin Skinner, 'John Milton and the Politics of Slavery', Prose Studies, 23:1 (2000), pp. 1-22.

${ }^{45}$ Mary Nyquist, 'Slavery, Resistance, and Nation in Milton and Locke', in David Loewenstein and Paul Stevens (eds), Early Modern Nationalism and Milton's England (Toronto: University of Toronto Press, 2008), pp. 356-97, p. 357.

${ }^{46}$ Steven Jablonski, 'Ham's Vicious Race: Slavery and John Milton', Studies in English Literature 15001900, 37:1 (1997), pp. 173-90.

${ }^{47}$ Foxley, The Levellers, pp. 24-8; cf. also the discussion of benign collective sovereignty in Regall Tyrannie Discovered (London, 1647), p. 11.

${ }^{48}$ Regall Tyrannie Discovered, p. 11.
} 
status of those 'slaves and vassals born' who had no choice. ${ }^{49}$ But the flipside of this rhetoric was a belief, firstly, that some might not be freeborn and hence might be rightfully enslaved (under the secondary laws of nature which also allowed for the creation of government), and, secondly, that any who did submit to slavery had, by doing so, displayed a kind of servility which deserved such domination.

If any moral flaw could make a person unsuitable for, or disqualify them from, citizenship, it was servility. A slave was the antithesis of a citizen. To depict the people as apt to servility was to depict a citizen body which was liable to moral collapse rather then steadfast in the defence of liberty and rights. The Levellers apparently agreed with Milton that (in John Pym's words, quoted by Lilburne): 'A servile condition doth for the most part beget in men a slavish temper and disposition. ${ }^{50}$ This thought was a powerful source of moral condemnation of the people in Milton's rhetoric, but in spite of reporting the argument, the Levellers rarely dwelt on the possibility that the people had succumbed to such servility. Milton, by contrast, habitually used the pejorative language of slavery and servility (whether in English or Latin) to reflect on people's moral qualities. In the lofty opening passage of the Tenure of Kings and Magistrates, Milton argued that 'bad men' were 'all naturally servile' and thus prone to upholding tyrants. ${ }^{51}$ In 1660, Milton was still associating vice with servility, and arguing that monarchs wanted their subjects to be 'basest, vitiousest, servilest' and ultimately 'sheepishest'. ${ }^{2}$ In spite of this strong moral condemnation, Milton did suggest that these servile traits were the consequence of slavery. People could be 'enobl'd' by liberty, but conversely they could 'degeneratly' or with a 'degenerat and fal'n spirit' fail to recognise or embrace liberty; they could suffer 'debasement of mind' ${ }^{53}$ These terms suggest a process of debasement or degeneration due to circumstance; indeed in the last case Milton was explicit that this debasement was not 'natural' for an Englishman. ${ }^{54}$ The only Leveller writer who condemned the vices of servility in a similar way was Richard Overton, who developed at length the theme of the morally and intellectually debasing impact of 'generations of usurpers' since the Norman Conquest. He argued that the people had 'degenerated from being

\footnotetext{
${ }^{49}$ Defensio 4.1 .532 (Columbia 7.542 'homini ingenuo'; cf 'corpore atque animo ad servitutem natos' in the previous sentence and Columbia 7.546 'In libertate sunt nati'); Tenure CPW 3.237.

${ }^{50}$ Lilburne, Legal Fundamental Liberties, in Haller \& Davies p. 430.

${ }^{51}$ Milton, The Tenure of Kings and Magistrates (1649), in Neil H. Keeble and Nicholas McDowell (ed) The Complete Works of John Milton, Volume VI: Vernacular regicide and republican writings (Oxford: Oxford University Press, 2013), p. 251.

${ }^{52}$ CPW 7.460. Note the social status-based disdain in 'basest' which is contrasted with 'noble' earlier in the passage.

${ }^{53}$ CPW 5.1.441; CPW 7.455; CPW 2.226; CPW 3.344.

${ }^{54}$ CPW 3.344.
} 
men' and become 'unman'd', not in a gendered sense, but in the much more profound sense that they had become 'bestiallized in their understandings' and were 'as bruits'. ${ }^{55}$ This language then led Overton to the charge that the people had become 'contented slaves'. ${ }^{56}$ The people were still seen as victims - they were 'the poore deceived people' - and Nicholas McDowell has read this passage, in the context of Overton's vitalist belief-system, as an expression of Overton's 'vision of an egalitarian society where all humans were free to become truly human and so more divine. ${ }^{57}$ Nonetheless, when Overton described the people as 'stupid, and grosly ignorant' this began to make them seem complicit in their own oppression in a way which was rare in Leveller writing, and certainly resonated with Milton's much more frequent lamentations about the people's apparent willingness to embrace tyranny. ${ }^{58}$

Both Milton and Overton linked political servility with degeneration to the level of animals - seeing the people as capable of extreme degeneration from the ideals of citizenship. Overton thought that slavery had rendered people 'as bruits'; Milton too labelled as 'arrant beasts' those who showed themselves to be 'by nature slaves', and extended the animal metaphor: they were 'brutes' who might be 'stroked and tamed' into subservience again. ${ }^{59}$ Even here, however, a fascinating space opens up between Milton and Overton which suggests that the animal comparison functions rather differently. For McDowell, Overton's language of humanity and brutality was an expression of his materialist, monist, vitalist beliefs. Humans had the capacity to degenerate and become bestial, or to move towards the divine. ${ }^{60}$ Milton, at least later in his life, shared these heterodox materialist and vitalist views, and Fallon argues that his hierarchy of being was also a distinctively 'dynamic' one, where 'direction is more important than position. ${ }^{\prime 61}$ Nonetheless, Milton did not follow Overton's remarkable step of attributing human dominion over animals to human sin and imagining that the animals' innocence would be rewarded in heaven. ${ }^{62}$ Milton understood 'dominion' over animals to have existed, even before the Fall, as one of many forms of 'beneficent

\footnotetext{
${ }^{55}$ Richard Overton, A Defiance against all Arbitrary Usurpations (1646), p. 2.

${ }^{56}$ Ibid., p. 2.

${ }^{57}$ McDowell, The English Radical Imagination, p. 70.

58 Overton, A Defiance against all Arbitrary Usurpations, p. 2. Cf. Richard Overton, The Ordinance for Tythes Dismounted (1645), p. 6: the presbyters have discovered that the people won't oppose them, being 'either grosly ignorant, carelesse, or else cowardly and degenerate'.

${ }^{59}$ CPW 3.581.

${ }^{60}$ McDowell, The English Radical Imagination, pp. 65-70.

61 Stephen M. Fallon, Milton among the Philosophers: Poetry and Materialism in Seventeenth-Century England (Ithaca and London: Cornell, 1991), p. 103.

${ }^{62}$ Erica Fudge, Perceiving Animals: Humans and Beasts in Early Modern English Culture (Urbana and Chicago: University of Illinois Press, 2002), pp. 148-56.
} 
hierarchy. ${ }^{63}$ For Overton, to compare downtrodden people to animals was not to say that they should be subject to the dominion - however benevolent - of their superiors. For Milton, that was certainly the implication.

Servility might be circumstantial, but for Milton, unlike for the Levellers, it might also be natural. This raises the possibility that there were men who would always have to be excluded from citizenship. Bad men were 'naturally servile' and the virtuous were 'by right' the 'Maisters' of those bad men who were vicious enough to be tyrants. ${ }^{64}$ Servility - or at least natural servility - justified exactly the kind of political subjection which Milton elsewhere described as slavery. A people seeking the return of a king such as Charles I 'would show themselves to be by nature slaves, and arrant beasts; not fit for that liberty, which they cried out and bellowed for. ${ }^{65}$ Thus the naturally servile could actually deserve enslavement. But circumstantial servility, at least when it had been a process of degeneration which lasted generations and changed the character of a people or nation, could also, apparently rightly, invite servility. The ancient Britons, 'through long subjection, servile in mind, slothful of body', offered 'vows of perpetual subjection to Rome' in return for protection against barbarian attacks. The Saxons in turn degenerated, leaving them subject to Danish invasion, and prompting Milton to reflect that 'when God hath decreed servitude on a sinful Nation, fitted by thir own vices for no condition but servile, all Estates of Government are alike unable to avoid it. ${ }^{96}$ By contrast, even when the Levellers considered paradigmatic cases of national slavery, they saw that slavery as inflicted '(by force of Armes) in the nature of Turkish Ianisaries, or the Regiments of the Guards of France' rather than as deserved by the people subjected to it. ${ }^{67}$

The authors of the Agreement of the People saw that the nation was in danger of 'returning into a slavish condition', but the Levellers did not conclude that the people were slavish. ${ }^{68}$ They urged the English to 'speedily look about them, and act vigorously' to fend off this threat, and their more desperate pleas did come close to accusing their countrymen of defects in courage: 'if you sit still and yeeld up your selves, as contented slaves, I cannot see,

${ }^{63}$ Diane McColley, 'Beneficent Hierarchies: Reading Milton Greenly', in Charles W. Durham and Kristin Pruitt McColgan (eds), Spokesperson Milton (London and Toronto: Associated University Presses, 1994), pp. 231-48.

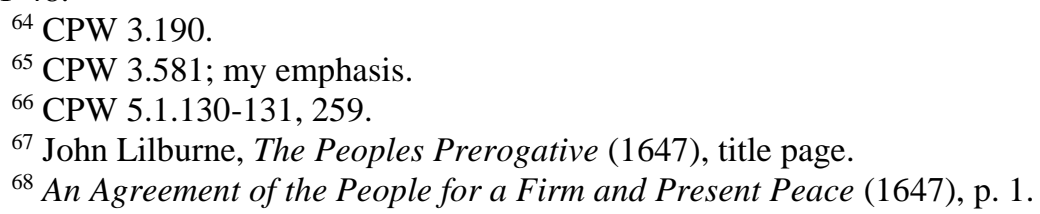


how you can be excused of madnesse or folly. ${ }^{99}$ Lilburne in a rasher moment asserted that 'no man can be a Slave but he that is afraid to die', and felt that the authorities would only achieve slavery 'by crushing in peeces (arbitrarily and tyrannically,) euery cordial hearted and Noun-Substantive English man, that dare peepe out in the least to owne his freedomes and liberties. ${ }^{70}$ In spite of this implied slur on those who survived to be enslaved, the Levellers, unlike Milton, described not the people but the people's oppressors as 'servile'. ${ }^{71}$

The Levellers' discourse of slavery emphasised the jeopardy the citizen body was in, but did not suggest that it was the qualities of the citizens which invited that, although a few servile men might choose to aid the oppressors. The Levellers remained able to envisage a citizen body largely united in moral courage, although their confidence did occasionally falter. In Milton's vision, by contrast, slavery left a moral taint on the enslaved, and those who willingly yielded to slavery almost by definition deserved it - even if that was just, as Christopher Hamel argues, because they were willing to connive in enslaving others. ${ }^{72}$ While dangerously servile individuals could undoubtedly endanger the state, Milton also imagined the mass of the people becoming servile. This raises again the question of the boundaries of his citizen body - whether these might ultimately be based not on the natural free-born status on which his grander statements about liberty rested, but on more compromised - or fallen divisions or gradations between the noble and the base, the upstanding and the servile. Indeed, slavery or servility was for Milton the most extreme way in which a man might fall short of the kind of manhood which enabled him to be both an autonomous household head and a citizen.

\section{GENDER AND CITIZENSHIP}

Gender, and in particular the complex expectations of 'manhood' which contrasted 'men' not only with women but with boys and with slaves, was an important element in both Leveller and Miltonic constructions of citizenship. While both assumed the exclusion of women from formal political citizenship, the ways in which they used gendered language helped to build differing images of citizenship.

\footnotetext{
${ }^{69}$ Lilburne, The Peoples Prerogative, title page; Overton, An Appeale, sig. C.

${ }^{70}$ John Lilburne, Strength out of Weaknesse (1649), p. 20; Lilburne, The Peoples Prerogative, p. 67.

${ }^{71}$ A Remonstrance of Many Thousand Citizens (1646), p. 11; [William Walwyn], The English Souldiers Standard to repair to (1649), unpaginated: referring to hostile propagandists and army officers.

${ }^{72}$ Hamel, 'The Republicanism of John Milton', p. 59.
} 
The Levellers and Milton shared a gendered value-system. Neither the Levellers nor Milton shook off the gendered norms of early modern politics, although Leveller women's petitions and Milton's divorce tracts (as well as his later poetry) actively reconsidered the significance of gender. Ann Hughes showed in an influential essay that the presentation of Leveller women in Leveller tracts served strategic purposes for the movement, and often centred on images of the household, rightly headed by a male husband and householder, though potentially horribly disrupted by the exigencies of 1640 s politics and the persecution of the male Leveller leaders. ${ }^{73} \mathrm{I}$ am not quite as convinced as Hughes that the male householder (rather than males lacking that status) was always the paradigmatic citizen for the Levellers, and we should certainly note the contexts in which Levellers did evoke female equality. Lilburne did so in looking back to Adam and Eve as the begetters of 'all and every particular and individuall man and woman, that ever breathed in the world since, who are, and were by nature all equall and alike in power, dignity, authority, and majesty, none of them having (by nature) any authority dominion or majesteriall power, one over or above another'. The implication, never spelled out, is that for authority to be exercised by men over women, just as for men over other men, 'mutuall consent and agreement, for the good benefit and comfort each of other' must seal a transaction. ${ }^{74}$ The text, however, slides back into the male world of politics without considering whether this agreement would inevitably arise to establish a gendered order of domestic authority. The boldest of the Leveller women's petitions claimed parity for women in spiritual matters ('an interest in Christ, equal unto men'), but only a 'proportionable' (rather than equal) 'share in the Freedoms of this Common-wealth' ${ }^{75}$ However expansive their language might sometimes have been, the Levellers never sought political rights for 'the poorest she' to match those which Rainborowe demanded for 'the poorest hee' at Putney. ${ }^{76}$

Milton's more extensive negotiations with gender are far too complex to do justice to here, and, like those of the Levellers, are ambivalent enough to have given rise to competing

\footnotetext{
${ }^{73}$ Ann Hughes, 'Gender and Politics in Leveller Literature', in Susan D. Amussen and Mark A. Kishlansky (eds), Political Culture and Cultural Politics in Early Modern England (Manchester: Manchester University Press, 1995), pp. 162-88.

${ }^{74}$ Lilburne, The Free-mans Freedom Vindicated, p. 11.

75 'To the Supreme Authority of England, the Commons Assembled in Parliament, the Humble Petition of Divers Well-affected Women' (5 May 1649), in The Moderate, 43, 1-8 May 1649.

${ }^{76}$ Patricia Crawford perhaps comes too close to suggesting that they were open to this possibility in Patricia Crawford, "The poorest she": women and citizenship in early modern England', in Michael Mendle (ed.), The Putney Debates of 1647: The Army, the Levellers and the English State (Cambridge: Cambridge University Press, 2001) pp. 197-218.
} 
interpretations. ${ }^{77}$ But the importance of the household for Miltonic politics is far clearer than for the Levellers: in both his divorce tracts and his political works, Milton likened or linked the male householder's autonomous exercise of authority over his wife and other subordinates in the household to his political freedom, and suggested that the political freedoms and duties of citizenship could not be meaningfully exercised by a man denied his authority at home. ${ }^{78}$ The authority of the male head of household should even extend, without the involvement of the state, to the ability to divorce an incompatible wife. ${ }^{79}$ While he conceded that, exceptionally, if a wife should 'exceed her husband in prudence and dexterity, and he contentedly yeeld' she should indeed have authority over him as 'the wiser should govern the lesse wise', he never stopped to consider whether such women might thus also be entitled to political citizenship. ${ }^{80}$

Women, then, were assumed to be excluded from citizenship. In addition, both the Levellers and Milton saw masculinity as a characteristic feature of good citizenship. Lilburne repeatedly praised the publications of Levellers or sympathisers, including the petition of 11 September 1648, as 'masculine'. ${ }^{81}$ Milton's ideal citizen was depicted as manly and masculine in strongly gendered terms, although Milton also sought to redefine that masculinity away from merely physical courage and did not see all males as necessarily endowed with it. ${ }^{82}$ But more subtle differences open up in the use of this evaluative language. The Levellers hardly ever accused anyone of effeminacy (although Walwyn did throw the accusation back at Thomas Edwards), and although they sometime referred to 'weak' or 'silly' women they did so in ironic tribute to the ordeals these women had faced or the wit and strength they had mustered, leaving an impression of women transcending the assumed

\footnotetext{
${ }^{77}$ For an overview, see Catherine Gimelli Martin, 'Introduction: Milton's Gendered Subjects', in Catherine Gimelli Martin (ed.), Milton and Gender (Cambridge: Cambridge University Press, 2005), pp. 1-15. Readings challenging Milton's reputation for misogyny have often focused on Paradise Lost, influentially read by Diane McColley, Milton's Eve (Urbana: University of Illinois Press, 1983); David Williams, Milton's Leveller God (Montreal and Kingston: McGill-Queen's University Press, 2007) claims Milton as a feminist. For a more negative view, see Diane Purkiss, 'Whose Liberty? The Rhetoric of Milton's Divorce Tracts', in McDowell and Smith (eds) The Oxford Handbook of Milton, pp. 186-99.

${ }^{78}$ CPW 2.229-30; 2.438; 2.632; 4.625; 3.236.

${ }^{79}$ CPW 2.347, 353.

${ }^{80}$ CPW 2.589.

81 John Lilburne, The Prisoners Plea for a Habeas Corpus (4 April, 1646), unpaginated; Lilburne, The Peoples Prerogative, unpaginated Proem; Lilburne, The legall fundamentall liberties, p. 20; John Lilburne, An Impeachment of High Treason against Oliver Cromwel (1649), p. 5.

${ }^{82}$ Gina Hausknecht, 'The Gender of Civic Virtue', in Catherine Gimelli Martin (ed), Milton and Gender, pp. 19-33.
} 
limitations of their sex. ${ }^{83}$ Indeed, a Leveller woman might even act 'like a true bred Englishwoman', a phrase which comes close to creating a solid national body of women which compares with Lilburne's 'free-born Englishmen'. ${ }^{84}$ This was where Milton's use of language diverged from the Levellers': not only did he explicitly assert that women were 'an inferiour sexe', ${ }^{85}$ but he also far more actively mobilised the value-system of gender not just to praise good citizens but also to denigrate those men who fell short of this, whether an individual opponent like Salmasius, 'effeminate and Uxorious Magistrates' such as Charles I, or simply 'unmanly' citizens who could not be relied upon to uphold the cause of liberty. ${ }^{86}$ By using gender not just to assert the positive values of citizenship, but to cast doubt on the fitness of all men to live up to those values, Milton's rhetoric was in danger of fracturing rather than building up the citizen body.

\section{CONCLUSION}

The Levellers and Milton used shared arguments to make the case for an England not dependent on the will of a king, or of any arbitrary ruler. In discussing original freedom, consent, and political enslavement they used the same essential building-blocks to construct their arguments, building-blocks drawn from both 'liberal' and 'republican' traditions. Much of their positive evaluative vocabulary was the same: they valued vigorous, manly action in defence of liberty, based on reason and understanding. However, both theories and vocabulary could be differently deployed, and the resulting depictions of citizenship are strikingly different - challenging the claims of scholars who wish to assimilate Milton's politics to Leveller thought. Milton's vision of citizenship was more unsettled and ambivalent, oscillating between hope and doubt about the capacity of the people to rule themselves. When he invoked the authority of the 'people', it was a rather undefined or positively fictive body, which could be spoken or acted for by virtuous minorities. When he linked irrationality, immorality and servility with the 'vulgar' or 'base', he cast doubt on the capacity of the mass of the people ever to achieve the virtue necessary to speak for the people. When he likened men to women, children, or slaves - those whose status or

${ }^{83}$ Walwyn, A vvhisper in the eare of Mr. Thomas Edwards minister, p. 8; Overton, The Commoners Complaint, pp. 17-18; William Walwyn, Walwyns Jvst Defence (1649), pp. 16-17.

${ }^{84}$ Overton, The Commoners Complaint, p. 17.

${ }^{85}$ CPW 2.589.

${ }^{86}$ CPW 4.1.312; CPW 3.421; CPW 7.362; Hausknecht, 'The Gender of Civic Virtue', pp. 21-4 rightly points out that although Milton did seem to fear a feminine kind of 'contagion', he also depicted men as falling short of being men through becoming boyish or bestial, as in this quotation where the 'unmanly' are compared to boys and babies. 
capacities put them outside the bounds of citizenship - he cast doubt on whether the status of a man, or even a male householder, was enough to secure the status of citizen, or at least raised the possibility of gradations within citizenship. By contrast, the Levellers' mantra of the 'free-born Englishman' was designed to affirm that all men born in England qualified and their focus on ensuring political equality between citizens was central to their agenda. In practice they envisaged some exclusions from electoral citizenship based on dependence, but the rhetoric of their writings functioned to build up the solidity and uniformity of the citizenbody of free-born Englishmen, even while urging readers to live up to that perhaps demanding status.

What role were these citizens, as imagined by Milton and by the Levellers, to play? Both Milton and the Levellers were writing to address moments of political crisis and political possibility: not politics as usual within a constitutional framework, but moments when the framework itself was under threat or was being remade. For both Milton and the Levellers the people had a crucial role in achieving and authorising such constitutive actions. In their right 'of choosing, yea of changing their own Goverment', in Milton's terms, or in subscribing the third Agreement of the People, the final constitutional outline promoted by the Levellers, the people were exercising their ultimate sovereignty. ${ }^{87}$ But such constitutive acts of sovereignty stand at a distance from day-to-day governance. How regularly, and in what form, was popular power supposed to flow through the acts of everyday government?

Michael Zuckert suggests that Milton's framing of the right of the people to change their government in the Tenure 'collapses the people's constitutive power and their governing power': there is no space for constitutionalism to stand in the way of the people's will. ${ }^{88}$ Yet we have very little sense from Milton of what role the people should play outside times of crisis; and in times of crisis, it seems that the multitude will contribute to the momentum but may well defect from the cause, leaving a wiser minority to cope with the aftermath. Richard Tuck has suggested a new genealogy for modern democracy, running via Bodin, Hobbes, and Rousseau, and resting on the distinction between sovereignty and government, which enabled a 'sleeping' democratic sovereign to perform only occasional acts of sovereignty, while government was carried out without the direct involvement of the people. ${ }^{89}$ Although Milton

\footnotetext{
${ }^{87}$ CPW 3.207.

${ }^{88}$ Michael P. Zuckert, Natural Rights and the New Republicanism (Princeton: Princeton University Press, 1994), p. 81.

${ }^{89}$ Richard Tuck, The Sleeping Sovereign: The Invention of Modern Democracy (Cambridge: Cambridge University Press, 2015).
} 
did not separate sovereignty and government in this way, in practice he seemed happy for popular authorisation of a government to become detached from the exercise of power, which in 1659-60 he envisaged being done through a perpetual senate. Thus his high aspirations for citizen virtue might come to be expressed through a tiny group of active governors who did not even fulfil the Aristotelian requirement of ruling and being ruled in turn.

The Levellers' vision involved precisely the kind of fluid continuing relationship between popular and institutional sovereignty which Zuckert suggests for Milton. ${ }^{90}$ Since the electoral role of the whole population of independent free-born Englishmen was central, we might assume that this represented a step away from the virtue-led ideals of classical republicanism, towards a wide but shallow kind of electoral citizenship. The Levellers gave the people the defensive role of curbing power and enforcing accountability ${ }^{91}$ - through annual elections, the right of petitioning, a recall mechanism for errant MPs (in one 1647 document), ${ }^{92}$ and - in extremis if not in everyday politics under a new constitution - direct action of unspecified but potentially violent kinds. This might seem to reduce the people's role to a kind of selfdefence rather than a positive political wisdom. But this view underestimates the Levellers' generous assessment of the people's potential, which partook of many of the moral and intellectual ideals which republicans might have thought suitable only for the members of a more narrowly-defined citizen body, or only for people participating in the higher layers of that citizen activity. Voting itself could constitute a form of active citizenship; ${ }^{93}$ in the context of the increasingly politically-charged electoral activity which voters had experienced in the late 1620s and in 1640, the Levellers may well have imagined their broader electorate of well-informed and rational free-born Englishmen voting on the basis of candidates' proposed priorities and allegiances, and not just voting to throw out corrupt sitting representatives. One transitory proposal made by Lilburne or a supporter in 1645 suggested an even more meaningful form of citizen participation, proposing that 'every free-man of England, who is able, would bestow his servic[e] one yeere at least, freely for the good of the Civill State, in any Place or Office of Trust, whereof his skill and breeding doe fit him, to

\footnotetext{
${ }^{90}$ Foxley, The Levellers, p. 77.

${ }^{91}$ Cf. John P. McCormick, Machiavellian Democracy (Cambridge: Cambridge University Press, 2011); Jason S. Maloy, The Colonial American Origins of Modern Democratic Thought (Cambridge: Cambridge University Press, 2008) for suggestive accounts of robust democratic accountability mechanisms in early modern thought and practice, going beyond mere electoral accountability.

92 Overton, An Appeale, 'Certain Articles', p. 32.

${ }^{93}$ Baker, 'Franchise Debate', p. 122.
} 
be most capable.' This 'skill and breeding' would not necessarily be associated with high birth: suitable men in financial need would be paid to enable them to undertake it. ${ }^{94}$

Harrington's 'modern' republicanism was a 'democracy' where the people were distanced from power by tiers of election and the popular assembly protected the people's interests purely by the exercise of a non-deliberative veto. The classical republican reliance on the wisdom and virtue of a few still pervaded Oceana's hierarchical constitution, but this 'democracy' included a role for those who lacked that virtue. Milton maintained a classical republican commitment to a citizenship which might be deeply demanding - but was also apparently increasingly restricted, and might at most have the 'the resemblance \& effects of a perfect democracie'. ${ }^{95}$ The Levellers' model of both wide and meaningful participation was in dramatic contrast to both. Nedham was only slightly exaggerating when he said that the Levellers' proposals put 'the whole multitude of the people into the equall exercise of the Supreme Authority' - his definition of democracy.

94 [John Lilburne or supporter?], England's birth-right justified against all arbitrary usurpation (1645), unpaginated.

${ }^{95}$ CPW 7.331 (my emphasis). 